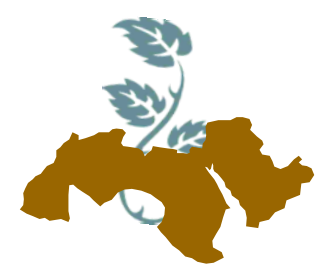

\title{
FUNCTIONAL, RHEOLOGICAL AND SENSORY CHARACTERISTICS OF DEFATTED-HYDROLYZED RICE BRAN AS FAT REPLACERS IN PREPARED BISCUIT
}

\author{
[112] \\ Madkour A.H., Magda H. Allam, Abdel Fattah A.A. and Kishk* Y.F.M. \\ Food Sci. Dept., Fac. of Agric., Ain Shams Univ., P.O. Box 68 Hadayek Shoubra, 11241, Cairo, \\ Egypt \\ *Corresponding author: Yasser F.M. Kishk, Dept. of Food Sci., Fac. of Agric., Ain Shams Univ., Cairo, \\ Egypt. E-mail: yasser keshk@agr.asu.edu.eg \\ yasserkishk@gmail.com
}

Keywords: Defatted Rice Bran, Emulsifying activity, Foam activity, biscuit-sensory characteristics

\section{ABSTRACT}

Defatted rice bran (DRB) and hydrolyzed defatted rice bran (DRBT) were prepared from rice bran meal (RBM). Proximate composition, oil and water binding capacities, emulsifying and foaming characteristics were determined. Effect of different substitution of DRB and DRBT as Fat replacers in biscuit on the farenograph parameters and sensory characteristics were also evaluated. The total protein, ash and crude fiber were significantly $(P \leq 0.05)$ increased in each of DRB and DRBT compared to RBM. Defatted rice bran protein hydrolyzed improved the DRBT water, oil absorption index being 1.7. Used each of DRB or DRBT gave high emulsifying activity and stability indices in casein model system. The same trend was observed with foam activity and stability indices in egg albumin system. farenogram parameters significant $(P \leq 0.05)$ affected by using DRB and DRBT. The prepared biscuits samples had high sensory scores with 10 to $50 \%$ DRB and DRBT attributes and recorded non-significant $(P \leq 0.05)$ differences compared to control sample.

\section{INTRODUCTION}

Rice is the second largest cereal crop produced worldwide, with a global production of 696 million metric tons of paddy rice in 2010 Dnosajj, (2010). Rice bran (RB) is one of the most important by-products of the rice milling process and is produced on a large scale yield. RB is regarded as a rich source of nutrition and bioactive compounds with antioxidant activities, including proteins, phenolic compounds. Due to hypoallergenic properties, RB protein is an excellent cereal protein and is as effective as soy protein for reduction of plasma cholesterol levels Morita, et al (1997). During 2014 Egypt produced six million tons of rice, ultimately yielding about 528,000 tons of bran FAO, (2017). Currently, rice bran is utilized mainly as stock feed, with a small amount also used for other purposes such as nutritional supplements, ingredients of microbiological media and extraction for cooking oil Yadav, et al (2011). Like other cereal grains, rice bran is rich in protein, with 12 to $16 \%$ of bran dry matter being protein Cheruvanky, et al (2004). However, despite the abundance of rice bran, more research has been carried out to develop rice bran protein-based products and, consequently, this rich protein source remains underutilized Uraipong and Zhao, (2015).

Rice bran contains an insignificant amount of protein (12 to $20 \%$ ), with high nutritional quality Jiamyangyuen, et al (2005), Fabian and Ju, (2011). The protein efficiency ratio of rice bran protein concentrate has been measured at 2.0 2.5 , it is also very digestible more than $(90 \%)$ Wang, et al (1999). Enzymatic hydrolysis does not affect the nutritional value of the proteins. Additionally, enzymatic hydrolysis can improve the physicochemical, functional, and sensory properties of native proteins Kristinsson and Rasco, (2000). 
Supplementation of heat stabilized rice bran up to $10 \%$ is more suitable for production of cookies Younas, et al (2011). After extraction of oil from rice bran, residue is known as de-oiled rice bran, also keep humans healthy due to low fat content. Defatted rice bran also possesses unique functional and nutritional properties. Keeping in view, the nutritional importance of defatted rice bran, made an attempt to prepare ready-to-eat breakfast cereals enhanced with defatted rice bran Charunuch, et al (2014). Al-Okbi, et al (2014) studied the production of corn flakes and tortillas chips, by supplementation of gelatinized corn flour with rice bran from 10 to $30 \%$ and conclude that the maximum breakdown viscosity and color quality was affected and sensory parameters decreased while protein percentage was increased depending on the level of rice bran.

This study aimed to prepare either defatted rice bran and rice bran treated by trypsin and their incorporation in biscuit as fat replacers. The oil and water binding capacity, emulsifying and foaming behavior were determined. In addition, function of DRB \& DRBT as a fat replacer, the rheology of dough and prepared biscuits characteristics were evaluated.

\section{MATERIALS AND METHODS}

\section{MATERIALS}

Wheat flour (Triticum aestivum), 72\% extraction was obtained from Five Stars Milling Company, Suisse governorate, Egypt. RBM was obtained from Agriculture Research Center, Giza, Cairo, Egypt. Purified Trypsin (EC 67/548 or EC 1999/45) was obtained from LOBA CHEMIE PVT.LTD.107 Wode House Road, Jehangir Villa, Colaba 400005 Mumbai. Crystal and fine white sugar, table salt, whole egg, palm oil, vanilla, milk powder and corn oil were purchased from local market, Cairo, Egypt.

\section{METHODS}

\section{Preparation of defatted rice bran}

The obtained (RBM) was used to prepare (DRB) as described by Wang et al (1999). RBM was stabilized using thermal treatment at $105^{\circ} \mathrm{C}$ for $20 \mathrm{~min}$. The oil was extracted five times for 12 $\mathrm{hr}$. each time by $\mathrm{n}$-hexane using ratio was $1: 3$ (W/V) at room temperature $25^{\circ} \mathrm{C} \pm 1$. Solvent was removed by drying in oven at $45{ }^{\circ} \mathrm{C} \pm 5$ for $6 \mathrm{hr}$. and the resultant milled was sieved to obtain the fine fraction (40 mesh). The DRB kept in polyethylene bags and stored at $4{ }^{\circ} \mathrm{C} \pm 2$ until used.

\section{Treatment of defatted rice bran treated by tryp- sin enzyme}

The DRB treated by trypsin enzyme according to the method investigated by Ashraf et al (2012). Treat $300 \mathrm{~g}$ DRB in one litter $0.1 \%$ trypsin of phosphate buffer solution at $\mathrm{pH}$ 7.8. Agitate the slurry for $6 \mathrm{hr}$. at $37^{\circ} \mathrm{C}$. Thereafter, the slurry dried in vacuum ovine at $50^{\circ} \mathrm{Cover}$ night. The dried material milled and sieved through $40 \mathrm{mish}$. The final product DRBT saved in a polyethylene page at 4 ${ }^{\circ} \mathrm{C}$ till use.

\section{Proximate composition}

Protein (Kjeldahl nitrogen estimation, $\mathrm{N} \times 5.7$ ), fat (soxhlet extraction), moisture, ash and crude fiber content of RBM, DRB and DRBT were determined according to AOAC, (2008). Nitrogen free extract (NFE) was calculated by difference.

\section{Water and oil binding capacity}

The water and oil binding capacities were determined according to the method reported by Sosulski et al (1976). One gram of sample was mixed with $10 \mathrm{ml}$ distilled water or refined corn oil in centrifuge tube. The tubes were kept at ambient temperature for $30 \mathrm{~min}$. then, centrifuged for 10 $\min$ at $2,000 \mathrm{xg}$. Water or oil binding capacity was expressed as the amount of water or oil absorbed by gram per gram sample or protein.

\section{Emulsifying activity index and emulsion stabil- ity}

Emulsifying activity index EAI $\left(\mathrm{m}^{2} \mathrm{~g}^{-1}\right)$ was determined at $\mathrm{pH} 7$ using casein $(5 \mathrm{mg} / \mathrm{ml}$ aqueous solution) as a model system according to the method described by Pearce and Kinsella, (1978) and its modification by Cameron et al (1991). Ten $\mathrm{ml}$ corn oil and $30 \mathrm{ml}$ casein aqueous solutions contained $0.17 \%(\mathrm{w} / \mathrm{v})$ of DRB and DRBT were used. The mixtures were homogenized in Virtis homogenizer (Model 6-105 AF) at 10,000 rpm for $60 \mathrm{sec}$., then the emulsion transferred to the $100 \mathrm{ml}$ glass beaker. Emulsion $(0.1 \mathrm{ml})$ was immediately taken from the bottom of the beaker and diluted to $50 \mathrm{ml}$ with $0.1 \%$ sodium dodecyl sulfate. The absorbance of the diluted emulsion was measured at $500 \mathrm{~nm}$ in Jenway spectrophotometer. The initial A500nm measurement was taken to be the emulsifying activity, while emulsion stability was measured at A500nm every 20 min. Emulsifying activity 
index (EAI) and emulsion stability (ESI) were calculated according the following equation:

$$
E A I \text { or } E S I=\frac{2 \times 2.303 \times A_{500 \mathrm{~nm}} \times \text { dilution }}{L \times C \times(1-\varnothing)}
$$

Where: $\mathrm{L}=$ length of cuvette, $\mathrm{C}=$ sample mass $\mathrm{g} / \mathrm{m}^{3}$ in original aqueous phase, $\varnothing=$ volume of fraction of the dispersed phase

\section{Foaming capacity (FC) and foam stability (FS)}

The ability of DRB and DRBT to enhance the foam capacity of $1 \%$ egg albumin in water and its stability was evaluated according to the method of Narayana and Narasinga Rao, (1982). The foam model system contains $0.05 \%$ of DRB or DRBT at $\mathrm{pH}$ 7. The volume of foam in $\mathrm{cm}^{3}$ measured at 30 sec. after whipping for $1 \mathrm{~min}$. was reported as foam capacity. The volume of foam after holding for 20 , 40 and $60 \mathrm{~min}$. was expressed as foam stability.

\section{Farenograph test}

Farenograph properties were evaluated using Brabender Farenograph (Brabender $\mathrm{GmbH}$, Duisburg, Germany) according to ICC (2012). Farenograph test was carried out to determine water absorption, arrival time, stability time, dough development time, departure time, mixing tolerance index, dough softening, time to breakdown, farinograph Quality Number, valorimeter number and dough weakening of wheat flour dough prepared from the various treatments under investigation.

\section{Preparation of vanilla biscuit}

The recipe of vanilla biscuit $100 \mathrm{~g}$ wheat flour, $57 \mathrm{~g}$ fat, $56.7 \mathrm{~g}$ fine sugar, $0.5 \mathrm{~g}$ sodium bicarbonate, $5.33 \mathrm{~g}$ fresh whole egg, $0.05 \mathrm{~g}$ vanilla, 0.1 $\mathrm{g}$ salt and $2 \mathrm{~g}$ starch. Mix the cooled palm oil with the sugar, and then add liquid and ammonium ingredients at the lowest speed in the planet mixer or dough-kneading machine to a uniform mass. Then add the flour with the baking powders and dry ingredients. Mix till a supple dough has been formed and everything is well mixed (scrape regularly). Dough was sheeted to $3 \mathrm{~mm}$ thickness. Circle cut the pieces were down by using of templates with outer diameter $5 \mathrm{~mm}$. The biscuit was baked at $180{ }^{\circ} \mathrm{C}$ for $20 \mathrm{~min}$. The biscuits were allowed to cool for $30 \mathrm{~min}$ at room temperature $\left(20^{\circ} \mathrm{C}\right)$ before sealed in metalized oriented polypropylene bags.
The fat replaced by DRB and DRBT at concentrations were $10,20,30,40$ and $50 \%$.

\section{Sensory evaluation}

Sensory evaluation was carried out by a trained panel of ten judges having experience in the field of sensory characteristics of biscuits. Sensory analysis of prepared biscuits with the blends was conducted for various sensory parameters by assigning scores for crust color: 1 = dull brown / whitish, 10 = golden brown; surface characteristics: 1 = rough surface, $10=$ smooth surface; crumb color: 1 = brown, 10 = creamish white; texture: 1 = hard/ brittle, 10 = crisp; taste: 1 = off flavor, off taste, 10 = normal and mouth feel: 1 = doughy/gritty, $10=$ clean mouth feel/no residue were analyzed. The overall quality score $(60)$ is the combined score of all these parameters Nandeesh, et al (2011).

\section{Statistical analysis}

The comparison between means was exposed by Duncan, (1955) multiple range at significance $(P \leq 0.05)$. Results followed by different alphabetical letters were significantly differed. ANOVA analysis (using PROC ANOVA procedure) was carrying out by Statistical Analysis System SAS program, (1996).

\section{RESULTS AND DISCUSION}

\section{Proximate composition}

The moisture, protein, total lipid, ash, crude fiber and nitrogen free extract contents of RBM, DRB and DRBT are shown in Table 1. The results revealed that $\mathrm{DRB}$ significantly $(P \leq 0.05)$ contain a high amount of moisture which was $10.4 \%$. The concentration process carried out on the RBM (15.1\% protein) lead to produce DRB and DRBT with high protein content being 19.8 and $20.4 \%$, respectively. Also, the protein concentration process positively affect in each of the ash and crude fiber content. Ash and crude fiber increased from 6.5 and $6.7 \%$ in the RBM to 7.9 and $8.3 \% ; 11.3$ and $14.3 \%$ in the DRB and DRBT, respectively with significant differences $(P \leq 0.05)$. The total lipid was decreased to the lowest level in the DRB and DRBT being 0.006 and $0.008 \%$, respectively with non-significant differences $(P \geq 0.05)$ between each other. The calculated nitrogen free extract ranged from $44.3 \%$ in DRBT to $53.6 \%$ in DRB. The obtained data closed with Yeom, et al (2010) and Godoy et al (2015). 
Table 1. Proximate analysis of rice bran meal (RBM), defatted rice bran (DRB) and defatted rice bran treated by trypsin (DRBT)

\begin{tabular}{|c|c|c|c|c|c|c|}
\hline \multirow{2}{*}{ Sample } & \multicolumn{5}{|c|}{ Proximate chemical composition } \\
\cline { 2 - 6 } & Moisture & $\begin{array}{c}\text { Protein } \\
\mathbf{( 5 . 7 )}\end{array}$ & Crud lipid & Ash & Fiber & NFE \\
\hline $\begin{array}{c}\text { Rice bran meal } \\
\text { ( RBM ) }\end{array}$ & $8.9^{\mathrm{c}}$ & $15.1^{\mathrm{c}}$ & $17.3^{\mathrm{a}}$ & $6.5^{\mathrm{c}}$ & $6.7^{\mathrm{c}}$ & $45.5^{\mathrm{b}}$ \\
$\begin{array}{c}\text { Defatted rice bran } \\
\text { (DRB) }\end{array}$ & $10.4^{\mathrm{a}}$ & $19.8^{\mathrm{b}}$ & $0.006^{\mathrm{b}}$ & $7.9^{\mathrm{b}}$ & $8.3^{\mathrm{b}}$ & $53.6^{\mathrm{a}}$ \\
$\begin{array}{c}\text { Defatted rice bran } \\
\text { treated by trypsin } \\
\text { (DRB) }\end{array}$ & $9.7^{\mathrm{b}}$ & $20.4^{\mathrm{a}}$ & $0.008^{\mathrm{b}}$ & $11.3^{\mathrm{a}}$ & $14.3^{\mathrm{a}}$ & $44.3^{\mathrm{b}}$ \\
\hline
\end{tabular}

Means in the same column with different letters are significantly different $(P \leq 0.05)$.

$\mathrm{NFE}=$ nitrogen free extract

\section{Water and oil binding capacities}

Water and oil binding capacities (g water or oil /g sample or g water or oil / g protein) were evaluated in DRB and DRBT. The obtained results are shown in Table 2. Significant differences $(P \leq 0.05)$ were observed between the mean values of DRB and DRBT. Defatted rice bran treated by trypsin had the highest water binding capacity value being $4.0 \mathrm{~g}$ water $/ \mathrm{g}$ sample and $19.7 \mathrm{~g}$ water/g protein compared to DRB. Patsanguan, et al (2014) reported that the rice bran had water absorption capacity $3.25 \mathrm{~g}$ water $/ \mathrm{g}$ sample. Dietary fiber in defatted rice bran contains a water binding capacity and higher fat binding Ardali, et al (2013). The higher water absorption capacity could be attributed to the presence of greater amount of hydrophilic constituents Akubor and Badifu, (2004). High water absorption of proteins helps to reduce moisture loss in backed bakery goods Prakash and Ramaswamy, (1996).

At the same time, the DRB appeared nonsignificantly $(P \geq 0.05)$ oil binding capacity $(2.0 \mathrm{~g}$ $\mathrm{oil} / \mathrm{g}$ sample and $10.1 \mathrm{~g}$ oil $/ \mathrm{g}$ protein) compared to the DRBT $(2.4 \mathrm{~g}$ oil $/ \mathrm{g}$ sample and $11.8 \mathrm{~g}$ oil $/ \mathrm{g}$ protein). Water oil binding index actually expressed about the performance of the tested samples, DRBT significantly $(P \leq 0.05)$ had the highest water oil binding index compared to the DRB. The obtained oil binding capacity in DRBT (1.7 wobi / g sample or wobi /g protein). Fat absorption is a physical entrapment of oil by a protein matrix. However, Lipophilicity of protein can affect in the fat absorption character (Kinsella, 1976). The high oil absorption capacity could suggest the presence of a large proportion of hydrophobic groups as compared with the hydrophilic groups on the surface of protein molecules Subagio, (2006).

Table 2. Water binding capacity ( $\mathrm{g} \mathrm{w} / \mathrm{g} \mathrm{s}, \mathrm{g} \mathrm{w} / \mathrm{g} \mathrm{p}$ ), oil binding capacity at original $\mathrm{pH}$ ( $\mathrm{g} \circ / \mathrm{g} \mathrm{s}, \mathrm{g} \circ / \mathrm{g} \mathrm{p})$ and water oil binding index of defatted rice bran and defatted rice bran treated by trypsin

\begin{tabular}{|c|c|c|c|c|c|c|}
\hline \multirow{3}{*}{ Materials } & \multicolumn{6}{|c|}{ Functional properties } \\
\hline & \multicolumn{2}{|c|}{ Water binding } & \multicolumn{2}{|c|}{ Oil binding } & \multicolumn{2}{|c|}{ Water oil binding index } \\
\hline & $g w / g s$ & $g w / g p$ & $g \circ / g s$ & $g \circ / g p$ & Wobi /g s & Wobi /g p \\
\hline $\begin{array}{l}\text { Defatted rice bran } \\
\text { (DRB) } \\
\text { Defatted rice bran } \\
\text { treated by trypsin } \\
\text { (DRBT) }\end{array}$ & $1.6^{\mathrm{b}}$ & $19.7^{\mathrm{a}}$ & $2.0^{\mathrm{a}}$ & $10.1^{a}$ & $0.8^{\mathrm{b}}$ & $0.8^{b}$ \\
\hline
\end{tabular}

Means in the same column with different letters are significantly different $(P \leq 0.05)$.

$\mathrm{W}=$ water, $\mathrm{P}=$ protein, $\mathrm{S}=$ sample, $\mathrm{O}=$ oil $\mathrm{B}=$ binding, $\mathrm{I}=$ index 


\section{Emulsifying activity (EA) and emulsion stability (ES)}

DRB and DRBT in model systems are presented in Table 3. The model system containing casein (5 $\mathrm{mg} / \mathrm{ml}$ aqueous solution) mixed with $0.17 \%$ from the DRB or DRBT at $\mathrm{pH}$ 7. DRB and DRBT in the model system were characterized by significantly $(P \leq 0.05)$ higher emulsion activity index (18.10 and $18.75 \mathrm{~m}^{2} / \mathrm{g}^{-1}$, respectively) than casein, $13.3 \mathrm{~m}^{2} / \mathrm{g}^{1}$. Defatted rice bran treated by trypsin significantly $(P \leq 0.05)$ had the highest emulsifying activity compared to other systems. Hydrolyze of DRB protein by trypsin lead to improve the emulsifying activity. Chobert, et al (1988) and Villaneuva et al (1999) reported that the emulsifying properties can be improved with a limited degree of hydrolyses. Bandyopadhyay, et al (2008) found that the rice bran protein peptide produced by papain modification have high protein solubility and emulsifying property.
The emulsion stability indices in different model systems were gradually decreased during $60 \mathrm{~min}$. of holding time with significant differences $(P \leq 0.05)$. The emulsion stability index after $60 \mathrm{~min}$. of emulsion that prepared using DRBT was significantly $(P \leq 0.05)$ better than the emulsion stability index of emulsion prepared using DRB with values were 9.25 and $8.05 \mathrm{~m}^{2} / \mathrm{g}^{-1}$, respectively. The solubility of the protein could be attributed to the net charge of peptides and surface hydrophobicity Sorgentini and Wagner, (2002). The emulsion property results of rice bran protein were closely relate with protein solubility Jongjareonrak, et al (2015). At the same time, casein appeared significantly $(P \leq 0.05)$ low stability of emulsion during holding time compared to other examined systems. Petruccelli and Anon, (1994) reported that emulsifying properties are closely associated with protein surface hydrophobicity.

Table 3. Emulsifying activity and emulsion stability indices $\left(\mathrm{m}^{2} \mathrm{~g}^{-1}\right)$ of defatted rice bran and defatted rice bran treated by trypsin DRBT in model system ( $5 \mathrm{mg}$ Casein/ $\mathrm{ml}$ aqueous solution $+0.17 \%$ rice preparations) at original $\mathrm{pH}$

\begin{tabular}{|c|c|c|c|c|}
\hline \multirow{2}{*}{ Sample } & \multirow{2}{*}{$\begin{array}{l}\text { Emulsion activity } \\
\text { index (zero time) }\end{array}$} & \multicolumn{3}{|c|}{ Emulsion stability index } \\
\hline & & $20 \mathrm{~min}$. & $40 \mathrm{~min}$. & $60 \mathrm{~min}$. \\
\hline Casein ( \%) & $13.35^{\mathrm{Ca}}$ & $9.35^{\mathrm{Cb}}$ & $7.20^{\mathrm{Cc}}$ & $6.70^{\mathrm{Cd}}$ \\
\hline $\begin{array}{l}\text { Defatted rice bran } \\
\text { ( DRB ) } \\
\text { Defatted rice bran } \\
\text { treated by trypsin } \\
\text { ( DRBT) }\end{array}$ & $18.10^{\mathrm{Ba}}$ & $11.75^{\mathrm{Bb}}$ & $10.00^{\mathrm{Ac}}$ & $9.25^{\mathrm{Ad}}$ \\
\hline
\end{tabular}

Means in the same column with different capital letters are significantly different $(P \leq 0.05)$.

Means in the same row with different small letters are significantly different $(P \leq 0.05)$.

\section{Foaming capacity (FC) and foam stability (FS)}

Foaming is another functional property of protein. Foam is a colloid in which many gas bubbles are trapped inside a liquid or solid. Small air bubbles are covered by thin liquid films. Foam can be formed by whipping air into liquid as much and fast as possible Jongjareonrak, et al (2015).

Foam capacity and stability $\left(\mathrm{cm}^{3}\right)$ of DRB and DRBT in model systems presented in Table 4. The model systems containing $10 \mathrm{mg}$ egg albumin $/ \mathrm{ml}$ aqueous solution mixed with $0.05 \%$ DRB or DRBT at $\mathrm{pH}$ 7. The model system contained DRBT had significantly $(P \leq 0.05)$ the highest foam capacity value $687 \mathrm{~cm}^{3}$ compared to egg albumin that had $640 \mathrm{~cm}^{3}$. According to the obtained results the hydrolyzed proteins enhanced the DRBT mode of action as a foam stabilizer in the egg albumin foaming system. Tang, et al (2003) reported that the formation of foam requires that proteins should solubilize in the aqueous phase and rapidly unfold to form a cohesive layer of protein around gas/air droplets. The DRB came in the second order with mean value was $657 \mathrm{~cm}^{3}$. On contrary, egg albumin system had the lowest foam capacity value $\left(640 \mathrm{~cm}^{3}\right)$ with significant differences compared to either DRB or DRBT. On the other hand, with increasing the holding time, the foam volumes in all model systems were broken down. The foam stability values were significantly reduced after 60 $\min$. 
The foam stability of system prepared using DRBT was significantly $(P \leq 0.05)$ stable than that of system prepared using DRB or egg albumin alone. In foams, the pressure in the dispersed phase is always higher than the pressure in the continuous phase. These pressure difference is given by the Laplace equation $(\Delta \mathrm{P}=2 \mathrm{y} / \mathrm{r})$ where $\mathrm{y}$ is the interfacial tension and $r$ is the radius of the gas bubbles. This capillary pressure causes drainage and thinning of the liquid film and eventual collapse of the film Bergeron, (1999), Stubenrauch and Klitzing, (2003). According to the Laplace equation the DRBT or DRB had positive effects on the interfacial tension and the gas bubbles radius to increase the thickening of the liquid film and prevents its thinning by decrease the pressure that lead to enhance the foam capacity and stability. The rapid protein adsorption at the air-water interface during bubbling or whipping, the ability to undergo rapid conformational change and rearrangement at the air-water interface, and the resultant rapid reduction in the surface tension are required for high foaming capacity Were, et al (1997), Chittapalo and Noomhorm, (2009).

Table 4. Foam activity (FA) and stability (FS) of defatted rice bran and defatted rice bran treated by trypsin in model system (10 $\mathrm{mg} \mathrm{Egg} \mathrm{albumin} / \mathrm{ml}$ aqueous solution $+0.05 \%$ rice preparations) at original $\mathrm{pH}$

\begin{tabular}{|c|c|c|c|c|}
\hline \multirow{2}{*}{ Sample } & \multirow{2}{*}{$\begin{array}{l}\text { Foam activity } \\
\text { (zero time) }\end{array}$} & \multicolumn{3}{|c|}{ Foam stability } \\
\hline & & $20 \mathrm{~min}$. & $40 \mathrm{~min}$. & $60 \mathrm{~min}$. \\
\hline Egg albumin & $640^{\mathrm{Ca}}$ & $540^{\mathrm{Ab}}$ & $480^{A c}$ & $407^{\mathrm{Bd}}$ \\
\hline $\begin{array}{l}\text { Defatted rice bran } \\
\text { ( DRB ) } \\
\text { Defatted rice bran } \\
\text { treated by trypsin } \\
\text { ( DRBT ) }\end{array}$ & $657^{\mathrm{Ba}}$ & $515^{\mathrm{Ab}}$ & $465^{\mathrm{Ac}}$ & $427^{\mathrm{Ad}}$ \\
\hline
\end{tabular}

Means in the same column with different capital letters are significantly different $(P \leq 0.05)$.

Means in the same row with different small letters are significantly different $(P \leq 0.05)$.

\section{Farinograph parameters of dough}

Effect of replacement the vanilla biscuit fat $(57$ \%) by DRB or DRBT as fat replacers on farinograph characteristics studied. The replacement levels were $0,10,20,30,40$ and $50 \%$. The obtained farinograph characteristics presented in Table 5. Water absorption was significant $(P \leq 0.05)$ increased with increasing DRB from $57.2 \%$ to $63.1 \%$ at replacement 10 and $50 \%$, respectively. Used the trypsin to hydrolyzed the DRB proteins lead to significant $(P \leq 0.05)$ increased the water absorption compared to untreated DRB. These results harmonized with the obtained data in Table (2) whereas, the water binding capacity was positive affected in the DRB enzymatic treated. Maximum water absorption value (65\%) was observed at replacement $50 \%$ DRBT compared to wheat flour that had $56.2 \%$. The increase in water absorption is due to the high fiber content of rice bran Salehi and Bibalan, (2012). Fiber is characterized by its high water holding capacity as reported by Holloway and Grieg, (1984). Also, Sudha, et al (2007) pointed out that water absorption and arri- val time increased as stabilized rice bran level increased in dough. Increase the hydroxyl group's number, which exist in the fiber structure lead to more water interaction through hydrogen bonding Rosell, et al (2001). Arrival time and Peak time not significant $(P \geq 0.05)$ affected at low replacement concentrations from zero to $20 \%$, but at replacement concentrations from 30 to $50 \%$ the mean values were significant $(P \leq 0.05)$ increased. Maximum arrival time and peak time values (4.2 and $10.7 \mathrm{~min}$ ) was observed at replacement $50 \%$ by DRBT. The stability time significantly $(P \leq 0.05)$ increased with increasing the replacement percent form either DRB or DRBT concentrations. The maximum mean value was $17 \mathrm{~min}$. observed at 30 and $40 \%$ DRBT. In contrarily the minimum mean value was 3 min. observed with wheat flour without prepared fat replacers. At the same time the departure time had the same trend that observed with stability time. Mixing tolerance index significant $(P \leq 0.05)$ negative affected by replacement using DRB or DRBT. The men values decreased with increasing the DRB or DRBT concentrations. Zhang and Moore, (1997) revealed that the dough 
Table 5. Farenograph parameters of wheat flour or prepared mixtures (for vanilla biscuit $57 \%$ fat) using defatted rice bran and enzymatic treated defatted rice bran as fat replacers at different replacement concentrations

\begin{tabular}{|c|c|c|c|c|c|c|c|c|c|c|c|c|}
\hline$\frac{\frac{0}{0}}{\frac{E}{\bar{N}}}$ & 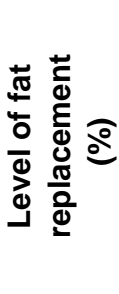 & 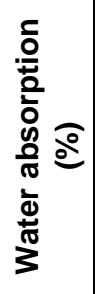 & 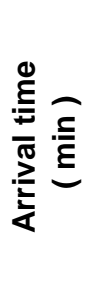 & 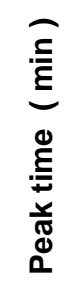 & 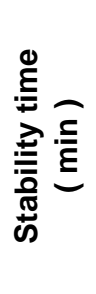 & 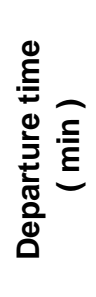 & $\begin{array}{l}5 \\
\underline{2} \\
E \\
\Sigma\end{array}$ & 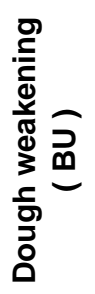 & 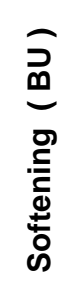 & 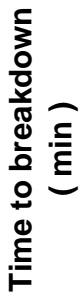 & $\begin{array}{l}z \\
\text { Z }\end{array}$ & 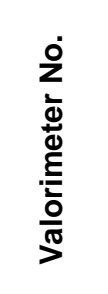 \\
\hline $\begin{array}{l}\text { Control } \\
\text { (wheat) }\end{array}$ & 0 & $56.2^{h}$ & $0.75^{c}$ & $1.7^{d}$ & $3.0^{c}$ & $3.7^{c}$ & $65^{\mathrm{ba}}$ & $70^{\mathrm{bdc}}$ & $55^{\mathrm{bc}}$ & $3.5^{\mathrm{b}}$ & $35^{\mathrm{b}}$ & $49.0^{\text {ef }}$ \\
\hline \multirow{5}{*}{ 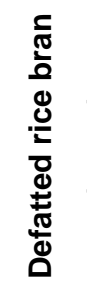 } & 10 & $57.2^{g}$ & $1.0^{c}$ & $1.5^{\mathrm{d}}$ & $3.2^{c}$ & $3.7^{c}$ & $75^{\mathrm{a}}$ & $100^{\mathrm{a}}$ & $75^{a}$ & $3.2^{b}$ & $32.5^{\mathrm{b}}$ & $45.5^{\mathrm{g}}$ \\
\hline & 20 & $59.2^{f}$ & $1.0 \mathrm{c}$ & $1.7^{d}$ & $2.5^{\mathrm{c}}$ & $3.5^{c}$ & $65^{\mathrm{ba}}$ & $95^{\mathrm{a}}$ & $70^{\text {ba }}$ & $3.2^{b}$ & $32.5^{b}$ & $45.0^{\mathrm{g}}$ \\
\hline & 30 & $61.1^{\mathrm{e}}$ & $1.0^{c}$ & $1.7^{d}$ & $7.0^{\mathrm{b}}$ & $8.0^{b}$ & $40^{c}$ & $95^{\mathrm{a}}$ & $65^{\text {ba }}$ & $3.5^{\mathrm{b}}$ & $35.0^{b}$ & $48.5^{\dagger}$ \\
\hline & 40 & $61.9^{d}$ & $1.0^{c}$ & $1.7^{d}$ & $6.7^{b}$ & $7.7^{\mathrm{b}}$ & $35^{\mathrm{dc}}$ & $90^{\mathrm{ba}}$ & $65^{\mathrm{ba}}$ & $3.2^{b}$ & $32.5^{b}$ & $46.5^{\mathrm{g}}$ \\
\hline & 50 & $63.1^{\mathrm{c}}$ & $1.5^{\mathrm{b}}$ & $2.0^{d}$ & $7.2^{b}$ & $8.5^{b}$ & $30^{\mathrm{dc}}$ & $80^{\text {bac }}$ & $65^{\mathrm{ba}}$ & $3.7^{\mathrm{b}}$ & $37.5^{b}$ & $49.5^{\text {edf }}$ \\
\hline \multirow{5}{*}{ 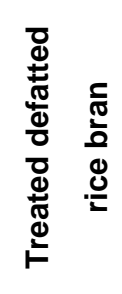 } & 10 & $59.7^{f}$ & $1.0^{c}$ & $1.5^{\mathrm{d}}$ & $3.5^{c}$ & $4.5^{c}$ & $55^{b}$ & $70^{\mathrm{bdc}}$ & $55^{b c}$ & $3.7^{\mathrm{b}}$ & $37.5^{b}$ & $51.0^{d}$ \\
\hline & 20 & $60.8^{\mathrm{e}}$ & $1.0^{\mathrm{C}}$ & $1.5^{\mathrm{d}}$ & $8.0^{b}$ & $9.0^{b}$ & $30^{\mathrm{dc}}$ & $55^{d}$ & $45^{\mathrm{dc}}$ & $3.5^{\mathrm{b}}$ & $35.0^{b}$ & $50.5^{\mathrm{ed}}$ \\
\hline & 30 & $62.3^{d}$ & $1.0^{c}$ & $8.7^{c}$ & $17.0^{\mathrm{a}}$ & $18.0^{a}$ & $20^{d}$ & $50^{d}$ & $20^{e}$ & $19.0^{a}$ & $19.0^{a}$ & $74.5^{\mathrm{c}}$ \\
\hline & 40 & $63.7^{\mathrm{b}}$ & $1.0^{c}$ & $9.7^{\mathrm{b}}$ & $17.0^{\mathrm{a}}$ & $18.0^{a}$ & $30^{\mathrm{dc}}$ & $60^{d c}$ & $35^{\mathrm{de}}$ & $20.2^{a}$ & $20.5^{\mathrm{a}}$ & $77.5^{\mathrm{b}}$ \\
\hline & 50 & $65.0^{\mathrm{a}}$ & $4.2^{\mathrm{a}}$ & $10.7^{\mathrm{a}}$ & $15.2^{\mathrm{a}}$ & $18.2^{\mathrm{a}}$ & $30^{\mathrm{dc}}$ & $60^{d c}$ & $40^{\mathrm{dc}}$ & $20.0^{a}$ & $20.0^{a}$ & $80.5^{\mathrm{a}}$ \\
\hline
\end{tabular}

Means in the same column with different letters are significantly different $(P \leq 0.05)$.

$\mathrm{BU}=$ Brabender unit

containing fine bran was less tolerant to mixing. Moreover, decreased the mixing stability may be caused by the disruption of the gluten networks by wheat bran particles. Degree of softening results appeared none or negligible significant $(P \leq 0.05)$ effect with the increasing of DRB concentrations. But it showed significant $(P \leq 0.05)$ decreased with the addition of DRBT. The maximum value (75 BU) was observed at $10 \%$ DRB. On the other hand, the minimum value was $20 \mathrm{BU}$ at $30 \%$ DRBT. Dough weakening not significant affected at all replacement concentrations compared to the control sample. Valorimeter number character had the same trend that observed with degree of softening. Replaced fat by DRB significantly $(P \leq 0.05)$ not effected in the valorimeter number. With addition, increased the DRBT lead to increase the valorimeter number at all used concentrations. The maximum value 80.5 was observed at $50 \%$ DRBT and the minimum value was 45 at $20 \%$ DRB. The rheological obtained data closed with Nandeesh, et al (2009).

\section{Sensory characteristics of vanilla Biscuits}

The data of sensory characteristics of vanilla biscuits prepared by DRB and DRBT at different concentrations presented in Table 6. The prepared biscuits samples using DRB appeared nonsignificant $(P \geq 0.05)$ differences in external color, surface characteristics, taste and mouth feel at all fat replacing levels compared to the control sample. With increasing the replacement level of biscuit fat some sensory characteristics were significant $(P \leq 0.05)$ increased. Replaced the fat by DRB improved the internal color with more creamish, texture with more crispiness and overall acceptability. It could be use DRB with replacement the $50 \%$ 
from the fat by DRB. Rice bran is associated with volatile compounds and its odor is composed of alcohols and carbonyls, which could be a hindering factor in its use as an ingredient in human foods Bor, (2003).

At the same time all the sensory characteristics were not much affected by replacement the biscuit fat by DRBT compared to the control sample with non-significant differences $(P \geq 0.05)$. The overall acceptability of DRBT sample at replacement was $50 \%$ had score 7.8 compared to the control sample was 7.7. From the obtained data it could be said that, replaced the vanilla biscuit fat by DRB or DRBT at levels from 10 to $50 \%$ not effected in the sensory characteristics. With addition of DRB some attributes were improved. Protein-enriched biscuits can be prepared by incorporating rice bran protein concentrate in the formulation without affecting sensory quality adversely. Addition of rice bran protein concentrate improved the protein content of biscuits at all levels of substitution Yadav, et al (2011). The obtained result agreed with the literature report that baked goods provide one of the most attractive possibilities of using rice bran as ingredient in that, it increased dough yield and contributed to attractive crumb and crust Saunders, (1990) and Bunde, et al (2010).

Table 6. Sensory evaluation of biscuits prepared using defatted rice bran or defatted rice bran treated by trypsin as fat replacers at different concentrations.

\begin{tabular}{|c|c|c|c|c|c|c|c|c|c|c|c|c|c|c|}
\hline \multirow[b]{2}{*}{ 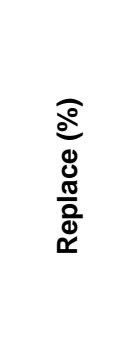 } & \multicolumn{7}{|c|}{ Defatted rice bran } & \multicolumn{7}{|c|}{ Defatted rice bran treated by trypsin } \\
\hline & 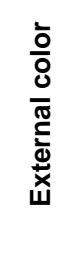 & 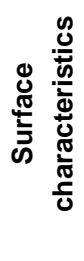 & $\begin{array}{l}\text { 흥 } \\
0 \\
\text { 을 } \\
\overline{ } \\
\frac{7}{0}\end{array}$ & & $\begin{array}{l}\stackrel{\oplus}{⿹} \\
\stackrel{\Xi}{\leftarrow}\end{array}$ & $\begin{array}{l}\bar{\Phi} \\
\stackrel{\Xi}{ \pm} \\
\frac{5}{5} \\
\stackrel{0}{\Sigma}\end{array}$ & 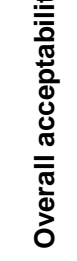 & 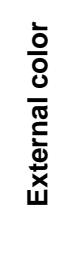 & 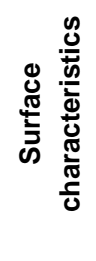 & 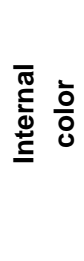 & 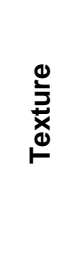 & $\begin{array}{l}\stackrel{\Phi}{⿹} \\
\stackrel{\sigma}{\sigma}\end{array}$ & 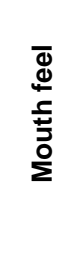 & 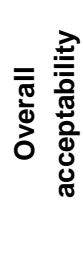 \\
\hline $\begin{array}{c}\text { Control } \\
100 \% \text { Fat }\end{array}$ & $6.9^{\mathrm{a}}$ & $6.9^{\mathrm{a}}$ & $7.1^{\mathrm{bc}}$ & $6.6^{\mathrm{c}}$ & $6.8^{\mathrm{a}}$ & $7.5^{\mathrm{ab}}$ & $7.0^{\mathrm{C}}$ & $8.0^{\mathrm{a}}$ & $7.8^{\mathrm{a}}$ & $7.1^{b}$ & $7.5^{\mathrm{a}}$ & $8.1^{a}$ & $7.7^{\mathrm{a}}$ & $7.7^{\mathrm{ab}}$ \\
\hline 10 & $6.6^{\mathrm{a}}$ & $7.4^{\mathrm{a}}$ & $6.8^{\mathrm{c}}$ & $7.0^{c}$ & $7.3^{\mathrm{a}}$ & $7.3^{\mathrm{b}}$ & $7.1^{\mathrm{c}}$ & $7.9^{\mathrm{a}}$ & $8.0^{\mathrm{a}}$ & $7.2^{\mathrm{b}}$ & $7.3^{\mathrm{a}}$ & $7.9^{\mathrm{a}}$ & $7.7^{\mathrm{a}}$ & $7.7^{\mathrm{b}}$ \\
\hline 20 & $7.2^{\mathrm{a}}$ & $7.6^{\mathrm{a}}$ & $7.5^{\mathrm{abc}}$ & $7.3^{\mathrm{cb}}$ & $7.6^{\mathrm{a}}$ & $7.8^{\mathrm{ab}}$ & $7.5^{\mathrm{abc}}$ & $8.1^{\mathrm{a}}$ & $8.0^{\mathrm{a}}$ & $8.5^{\mathrm{a}}$ & $8.2^{\mathrm{a}}$ & $8.2^{\mathrm{a}}$ & $8.0^{\mathrm{a}}$ & $8.2^{\mathrm{ab}}$ \\
\hline 30 & $7.6^{\mathrm{a}}$ & $7.7^{\mathrm{a}}$ & $8.1^{\mathrm{a}}$ & $8.2^{\mathrm{ab}}$ & $7.4^{\mathrm{a}}$ & $7.5^{\mathrm{ab}}$ & $7.8^{\mathrm{ab}}$ & $8.1^{\mathrm{a}}$ & $8.4^{\mathrm{a}}$ & $8.4^{\mathrm{a}}$ & $8.1^{\mathrm{a}}$ & $8.2^{\mathrm{a}}$ & $8.3^{\mathrm{a}}$ & $8.2^{\mathrm{a}}$ \\
\hline 40 & $7.4^{\mathrm{a}}$ & $6.7^{\mathrm{a}}$ & $7.8^{\mathrm{ab}}$ & $7.1^{c}$ & $7.3^{\mathrm{a}}$ & $7.2^{b}$ & $7.3^{b c}$ & $7.1^{\mathrm{a}}$ & $7.6^{\mathrm{a}}$ & $7.8^{\mathrm{ab}}$ & $8.1^{\mathrm{a}}$ & $7.8^{\mathrm{a}}$ & $8.1^{\mathrm{a}}$ & $7.7^{\mathrm{ab}}$ \\
\hline 50 & $7.3^{\mathrm{a}}$ & $7.6^{\mathrm{a}}$ & $8.1^{\mathrm{a}}$ & $8.3^{a}$ & $7.5^{\mathrm{a}}$ & $8.4^{\mathrm{a}}$ & $7.9^{\mathrm{a}}$ & $7.4^{\mathrm{a}}$ & $7.7^{\mathrm{a}}$ & $7.8^{\mathrm{ab}}$ & $7.9^{\mathrm{a}}$ & $7.6^{\mathrm{a}}$ & $8.5^{\mathrm{a}}$ & $7.8^{\mathrm{ab}}$ \\
\hline
\end{tabular}

Means in the same column with different letters are significantly different $(P \leq 0.05)$.

\section{CONCLUSION}

Based on this study, it could be concluded that DRB and DRBT could be used as fat replacers in preparation of biscuit at different replacement levels from 10 to $50 \%$ without drastic effect on technological quality and sensory properties of biscuit. Moreover, higher nutritive values of these biscuits are achieved.

\section{REFERENCES}

Akubor, P.I. and Badifu, G.I.O. 2004. Chemical composition, functional properties and baking potential of African bread fruit kernel and wheat flour blends. International J. of Food Sci. and Technology, 39, 223-229.

Al-Okbi, S.Y., Husseın, A.M.S., Hamed, I.M., Mohamed, D.A. and Helal, A.M. 2014. Chemical, rheological, sensorial and functional properties of gelatinized corn- rice bran flour composite corn flakes and Tortilla chips. J. of Food Processing and Preservation, 38, 83-89. 
AOAC 2008. Official Methods of Analysis Association of Official Analytical Chemists. $18^{\text {th }}$ ed., Maryland, USA.

Ardali, F.R., Hojjatoleslamy, M. and Shariaty, M.A. 2013. Production of a new functional rice bran beverage. African J. of Sci. and Research, 2, 20-23.

Ashraf S., Muhammad S., Saeed G., Sayeed S. A., Ali R., Saeed H. and Ahmed M. 2012. Effect of fat-replacement through rice milling by products on the rheological and baking behaviour of dough. African J. of Agric. Research, 7(44), 5898-5904.

Bandyopadhyay, K., Misra, G. and Ghosh, S. 2008. Preparation and characterisation of protein hydrolysates from indian defatted rice bran meal. J. of Oleo Sci., 57, 47-52.

Bergeron, V. 1999. Forces and structure in thin liquid soap films. J. Phys.Condens Matter. 11, 215-238.

Bor, S.L. 2003. Rice: Production and Utilization. Pub. Avi. Publishing Company, Inc. Westport C.T.

Bunde, M.C., Osundahunsi, F.O. and Akinoso. R. 2010. Supplementation of biscuit using rice bran and soybean flour. African J. of Food Agric. Nutrition and Development, 10, 40484059.

Cameron, D.R., Weber M.E., Idziak E.S., Neufeld R.J. and Cooper D.G. 1991. Determination of interfacial areas in emulsions using turbidimetric and droplet size data: correction of the formula for emulsifying activity index. J. of Agric. and Food Chemistry. 39, 655-659.

Charunuch, C., Limsangouan, N., Prasert, W. and Wongkrajang, K. 2014. Optimization of extrusion conditions for ready-to-eat breakfast cereal enhanced with defatted rice bran. International Food Research J., 21, 713-722.

Cheruvanky, R., McPeak, P., Cherukuri, R.S.V., Lynch, I. and Quresh, A.A. 2004. Method for treating hypercholesterolemia, hyperlipidemia, and atherosclerosis. United States Patent 430787.

Chittapalo, T. and Noomhorm, A. 2009. Ultrasonic assisted alkali extraction of protein from defatted rice bran and properties of the protein concentrates. International J. of Food Sci. and Technology, 44, 1843-1849.

Chobert, J.M., Bertrand-Harb, C. and Nicolas, M.G. 1988. Solubility and emulsifying properties of caseins and whey proteins modified enzymatically by trypsin. J. of Agric. and Food Chemistry, 36, 883-892.
Dnosajj, M. 2010. Food outlook global market analysis. Food and agriculture organization of the United Nations, Rome, $104 \mathrm{p}$.

Duncan, D.B. 1955. Multiple range and multiple Ftests. Biometrics 11(1), 1-42.

Fabian, C. and Ju, Y.H. 2011. A review on rice bran protein: its properties and extraction methods. Critical Reviews in Food Sci. and Nutrition, 51, 816-827.

FAO, 2017. http://faostat3.fao.org/home/

Godoy, R., Caliari, M., Júnior, M.S.S., da Silva, V.S.N., Benassi, M.T. and Garcia, M.C. 2015. Quinoa and rice co-products gluten freecereals: physical, chemical, microbiological and sensory qualities. J. of Food and Nutrition Research, 3, 599-606.

Holloway, W.D. and Grieg, R. 1984. Water holding capacity of hemicelluloses from fruits, vegetables and wheat bran. Food Sci., 44, 16321633.

I.C.C. Standards, 2012. Standard methods of the International Association for Cereal Science and Technology, ICC, Marxergasse 2, Vienna, AT, Austria.

Jiamyangyuen, S., Srijesdaruk V.and James Harper W. 2005. Extraction of rice bran protein concentrate and its application in bread. Songklanakarin J. of Sci. Technology, 27, 56-64.

Jongjareonrak, A., Srikok, K., Leksawasdi, N. and Andreotti, C. 2015. Extraction and functional properties of protein from de-oiled rice bran. CMU J. Nat. Sci., 14, 163-174.

Kinsella, J.E. 1976. Functional properties of proteins in foods: A survey. Critical Reviews in Food Sci. and Nutrition 7, 219-232.

Kristinsson, H.G. and Rasco, B.A. 2000. Biochemical and functional properties of atlantic salmon (Salmo salar) muscle proteins hydrolyzed with various alkaline proteases. J. of Agric. and Food Chemistry, 48, 657-666.

Morita, T., Oh-hashi, A., Takei, K., Ikai, M., Kasaoka, S. and Kiriyama, S. 1997. Cholesterol lowering effects of soybean, potato and rice proteins depend on their low methionine contents in rats fed a cholesterol-free purified diet. J.I of Nutrtion, 127, 470-477.

Nandeesh, K., Jyotsna, R. and Venkateswara Rao, G. 2009. Effect of differently treated wheat bran on rheology, microstructure and quality characteristics of soft dough biscuits. $\mathbf{J}$. of Food Processing and Preservation, 35, 179-200. 
Nandeesh, K., Rajiv, J. and Rao, G.V. 2011. Effect of differently treated wheat bran on rheology, microstructure and quality characteristics of soft dough biscuits. J. of Food Processing and Preservation, 35, 179-200.

Narayana, K. and Narasinga Rao M.S. 1982. Functional properties of raw and heat processed winged bean flour. J. of Food Sci., 47, 1534-1540.

Patsanguan, S., Hisaranusorn N., Phongthai S. and Rawdkuen S. 2014. Rice Bran Protein isolates: preparation and their physico-chemical and functional properties. Food and Applied Bioscience J., 3, 169-182.

Pearce, K.N. and. Kinsella J.E. 1978. Emulsifying properties of proteins: evaluation of a turbidimetric technique. J. of Agric. and Food Chemistry, 26, 716-723.

Petruccelli, S. and Anon, M.C. 1994. Soy protein isolate components and their interactions. J. of Agric. and Food Chemistry, 43, 1762-1767.

Prakash, J. and Ramaswamy H.S. 1996. Rice bran proteins: properties and food uses. Critical Reviews in Food Sci. and Nutrition, 36, 537-552.

Rosell, C.M., Rojas, J.A. and Debarber, B. 2001. Influence of hydrocolloids on dough rheology and bread quality. Food Hydrocolloid, 15, 7581.

Salehi, E.A. and Bibalan, S.G. 2012. The investigation on the effect of rice bran addition on the rheological and sensory properties of muffin cake. The $1^{\text {th }}$ International and The $4^{\text {th }}$ national congress on recycling of organic waste in Agriculture pp. 26-27 April, in Isfahan, Iran.

SAS Program, 1996. SAS/STAT User's guide Release 6.12 Edition. SAS Inst. Inc., Cary NC. USA.

Saunders, R.M. 1990. The properties of rice bran as a food stuff. Cereal Foods World, 35, 632636.

Sorgentini, D.A. and. Wagner, J.R. 2002. Comparative study of foaming properties of whey and isolate soy bean proteins. Food Research International, 35, 721-729.

Sosulski, F.W., Ganat M.D. and Slinkard A.F. 1976. Functional properties of ten legume flours. Canadian Institute of Food Sci. Technology J. 9, 66-74.

Stubenrauch, C. and Klitzing, R. 2003. Disjoining pressure in thin liquid foam and emulsion filmsnew concepts and perspectives. J. Phys. Condens Matter, 15, 1197-1232.
Subagio, A. 2006. Characterization of hyacinth bean (Lablab purpureus L. sweet) seeds from Indonesia and their protein isolate. Food Chemistry 95, 65-70.

Sudha, M.L.R., Vetrimani, K. and Leelavathi, K. 2007. Influence of fibre from different cereals on the rheological characteristics of wheat flour dough and on biscuit quality. Food Chemistry, 100, 1365-1370.

Tang, S., Hettiarachchy, N.S., Horax, R. and Eswaranandam, S. 2003. Physicochemical properties and functionality of rice bran protein hydrolyzate prepared from heat-stabilized defatted rice bran with the aid of enzymes. J. of Food Sci., 68, 152-157.

Uraipong, C. and Zhao, J. 2015. Rice bran protein hydrolysates exhibit strong in vitro $\alpha$ amylase, $\boldsymbol{\beta}$-glucosidase and ACE-inhibition activities. J. of the Sci. of Food and Agric., 96, 1101-1110.

Villaneuva, A., Vioque, J., Sanchez-Vioque, R., Clemente, A., Pedroche, J., Bautista, J. and Millan, F. 1999. Peptide characteristics of sunflower protein hydrolysates. J. of American Oil Chemists and Society, 76, 1455-1460.

Wang, M., Hettiarachchy, N.S., Qi, M., Burks, W. and Siebenmorgen, T. 1999. Preparation and functional properties of rice bran protein isolate. J. of Agric. and Food Chemistry, 47, 411416.

Were, L., Hettiarachchy, N.S. and Kalapathy, U. 1997. Modified soy proteins with improved foaming and water hydration properties. J. of Food Sci., 62, 821-823.

Yadav, R.B., Yadav, B.S. and Chaudhary, D. 2011. Extraction, characterization and utilization of rice bran protein concentrate for biscuit making. British Food J., 113, 1173-1182.

Yeom, H.J., Lee, E.H., Ha, M.S., Ha, S.D. and Bae, D.H. 2010. Production and Physicochemical properties of rice bran protein isolates prepared with autoclaving and enzymatic hydrolysis. J. of Korean Society for Applied Biological Chemistry, 53, 62-70.

Younas, A., Bhatti, M.S., Ahmed, A. and Randhawa, M.A. 2011. Effect of rice bran supplementation on cookie baking quality, Pak J. Agric. Sci., 48, 129-134.

Zhang, D. and Moore, W.R. 1997. Effect of wheat bran particle size on dough rheological properties. J. of the Sci. of Food and Agric., 74, 490-496. 